\title{
FALLING THROUGH THE GAPS OF THE REGISTRATION CONVENTION: A NEED FOR REVISION
}

\author{
By Alexia Katsiginis*
}

'Law must precede man into space'

- A G Haley ${ }^{1}$

\section{Introduction}

Space law is a child of the Cold War and the silent start of the space race. ${ }^{2}$ It did not take long after the launch of Sputnik 1 for the United States and the former Union of Soviet Socialist Republic (USSR) to come to the understanding that regulations were required to ensure that the use of space be reserved for 'peaceful purposes'. 3 Upon considering proposals from both the United States and the USSR regarding the establishment of a regulatory committee, the United Nations General Assembly (UNGA) finally formed the Committee on the Peaceful uses of Outer Space (COPUOS). ${ }^{4}$ The Committee was mandated with the task of recommending feasible and practical means of ensuring international co-operation in outer space. ${ }^{5}$ The international community showed a willingness to conform to legal rules in their exploration and use of the unknown universe and in 1967 UN COPUOS gave birth to the Outer Space Treaty. ${ }^{6}$

The Outer Space Treaty has been widely accepted as the Magna Carta of international space law and the heart of space use and exploration. ${ }^{7}$ As a general rule of treaty interpretation, the Vienna Convention on the Law of Treaties places limited importance on the travaux préparatoires but does not overlook the benefit of

Second year BCom LLB student, University of Pretoria.

AG Haley 'Space age presents immediate legal problems' (1959) 1 Proceedings of the Colloquium on the Law of Outer Space 5.

S Hobe 'Text of the 1967 Outer Space Treaty' in S Hobe, B Schmidt-Tedd \& KW Schrogl (eds) Cologne commentary on space law (2009) 4.

3 WA McDougal The heavens and the Earth - a political history of the space age (1997) 141.

UNGA res 1472 (XIV) 12 December 1959

Hobe (n 2 above) 5 .

Hobe (n 2 above) 13; Treaty on Principles Governing the Activities of States in the Exploration and Use of Outer Space, Including the Moon and Other Celestial Bodies (Outer Space Treaty).

7 H Qizhi 'The Outer Space Treaty in perspective' (1997) 25 Journal of Space Law 93. 
interpreting a treaty in light of its objectives and purpose. ${ }^{8}$ Most of the principles enshrined in the Outer Space Treaty are considered a codification of state practice and enjoy comfort in the certainty of their status as custom. ${ }^{9}$ The cornerstone of the Treaty is its definition of outer space as 'the common province of mankind'. ${ }^{10}$ The Outer Space Treaty was successful in providing the necessary foundation so that the development of space law could be brought in line with the principles of co-operation and due regard. Jakhu emphasises the importance of enhancing and protecting the common interest of mankind - in the exploration and use of outer space - to be of paramount importance when interpreting the international space regime. ${ }^{11}$ The common interest principle is re-enforced by the nonappropriation principle, which confirms that territorial sovereignty does not apply to outer space. ${ }^{12}$ These principles have subsequently been refined in the remaining four space law treaties, which together with the Outer Space Treaty - form the body of space law. ${ }^{13}$

Thirty years after the adoption of the most recent space law treaty - the Moon Agreement - the exploration of outer space has advanced considerably. ${ }^{14}$ It has become important to consider whether the current legal regime governing the activities in outer space is capable of regulating 'anticipated developments' of the 21st century. ${ }^{15}$ Judge Lachs recognises lawmaking in space as a continuous process underpinned by mankind's shared interest: ${ }^{16}$

The paramount consideration by which states should be guided in this law-making process for tomorrow, is 'the benefit and interest of all mankind'. This is repeatedly emphasised in all relevant instruments and stressed by writers on the subject. It is amplified by the desideratum that the exploration and use of space serve 'the betterment of mankind'.

The Registration Convention refines the broad objectives of the Outer Space Treaty by establishing a system of registration both to keep account of objects that have been launched into outer space, as well

8 Hobe (n 2 above) 13; Vienna Convention on the Law of Treaties (VCLT) art 31.

9 VS Vereshchetin \& GM Danilenko 'Custom as a source of international law of outer space' (1985) 13 Journal of Space Law 22.

10 Outer Space Treaty (n 6 above) art I.

11 R Jakhu 'Legal issues relating to the global public interest in outer space' (2006) 32 Journal of Space Law 32-33.

12 S Freeland \& R Jakhu 'Article II' in S Hobe, B Schmidt-Tedd \& KW Schrogl (eds) Cologne commentary on space law (2009) 48.

13 Agreement on the Rescue of Astronauts, the Return of Astronauts and the Return of Space Objects Launched into Outer Space (Return and Rescue Agreement); Convention on International Liability for Damage Caused by Space Objects (Liability Convention); Convention on the Registration of Objects Launched into Outer Space (Registration Convention); Agreement Governing the Activities of States on the Moon and Other Celestial Bodies (Moon Agreement).

14 Hobe (n 2 above) 14

15 Qizhi (n 7 above) 98.

16 M Lachs 'The international law of outer space' (1964) 133 Recueil Des Cours D'academie De Droit International 100. 
as to provide a means of vesting jurisdiction. ${ }^{17}$ The present position of law regulating and establishing jurisdiction in outer space is highly unsatisfactory. ${ }^{18}$ In 2002, Kopal proposed a re-examination of various provisions of the Registration Convention; specifically with regard to the adoption of more detailed requirements concerning space objects. 19

In this paper, I address the areas of law that have been left unregulated by the Registration Convention, as well as the need to develop the treaty using the cornerstones of space law as a foundation for such development. My first enquiry relates to the definition of a space object and the implications of limiting the treaty's scope to 'objects launched into earth's orbit or beyond'. Further, to what extent can this definition accommodate the registration of objects that are constructed in outer space? My second enquiry focuses on a lacuna that is largely unaddressed by space law in general and does not only lack in the Registration Convention. Currently, there is no system regulating the status of objects that are either wholly or partly constructed using lunar resources. It is questionable whether such a construction would pass the environmental threshold required by the due regard principle. However, should such a construction be deemed lawful it is uncertain to what extent a state may lawfully exercise jurisdiction over such an object without its authority being deemed an act of national appropriation. In this paper I will not attempt to creatively interpret available space law in order to accommodate missing regulations. Instead, I rely on the core of space law represented by the Outer Space Treaty - to provide a contextual backdrop against which the above questions can be answered or highlighted as incomplete.

\section{Jurisdiction in outer space}

The Outer Space Treaty first provided the notion of jurisdiction but was later better regulated by way of the Registration Convention. Space law provides that a state 'on whose registry an object launched into outer space is carried shall retain jurisdiction and control over such object [...] while in outer space. 20 Jurisdiction can be divided into three categories, namely: ${ }^{21}$

B Schmidt-Tedd \& S Mick 'Article VIII' in S Hobe, B Schmidt-Tedd \& KW Schrogl (eds) Cologne commentary on space law (2009) 149.

18 B Cheng 'Nationality for spacecraft?' in F von der Dunk et al (eds) Air and Space Law: Essays in Honour of Henri A Wassenbergh (1992) 155

19

$M$ Williams 'Final proposal on the review of space law treaties in view of commercial space activities - concrete proposals' (2002) New Delhi Conference. 20 Outer Space Treaty (n 6 above) art VIII; Registration Convention (n 13 above) art 2.

21 B Cheng 'Liability regulations applicable to research and invention in outer space and their commercial exploitation' in S Mosteshar (ed) Research and invention in outer space - liability and intellectual property rights (1995) 72. 
(a) territorial jurisdiction, relating to the jurisdiction a state enjoys over its own territory;

(b) quasi-territorial jurisdiction, relating to the jurisdiction a state enjoys over its own space object; and

(c) personal jurisdiction, relating to the jurisdiction a state enjoys over its nationals, whether natural or corporate persons.

Each of the above categories is accompanied by legislative supremacy to 'make binding laws within [a state's] territory.' 22 Territorial jurisdiction has been expressly prohibited by way of the nonappropriation principle, providing: ${ }^{23}$

Outer Space, including the Moon and other celestial bodies, is not subject to national appropriation by claims of sovereignty, by means of use or occupation, or by any other means.

In effect, this provision creates an extra-territorial environment by implying that outer space may not be appropriated to serve the exclusive interests of a single state. ${ }^{24}$ Both quasi-territorial and personal jurisdiction is possible. However, the two categories function within a hierarchical relationship where quasi-territorial jurisdiction overrides personal jurisdiction. 25

The Registration Convention grapples with the concept of jurisdiction by confining it to a framework of qualifying criteria. The treaty places an obligation on states party to maintain a national registry of space objects. ${ }^{26}$ To acquire jurisdiction and control, national registration of the space object is required, without which, jurisdiction is not feasible. ${ }^{27}$ It appears that the treaty has failed to



Cheng (n 21 above) 76; Outer Space Treaty (n 6 above) art IX; Schmidt-Tedd (n 17 above) 155; N Rodrigues 'The United Nations register of objects launched into outer space' in S Hobe et al (eds) Proceedings of the project 2001 plus workshop: current issues in the registration of space objects (2005) 25; S Hobe 'Legal aspects of space tourism' (2007) 86 Nebraska Law Review 447. Stephan Hobe supports the view that the Registration Convention requires development, citing the decrease in the registration of space objects as an indication of the treaty's ineffectiveness. Further UN COPUOS has considered altering the treaty to encourage states to follow a system of registration. I tend to share the same concern as expressed by Hobe regarding the vague procedures for registration. The Registration Convention fails to address numerous issues that have left it somewhat static. Amongst such issues is that of the disclosure of information that would ordinarily be required by a system of registration and whether the ideal manner of registering a space object -including its space debris - can overcome its practical limitations. State practice regarding the registration of space objects can be divided into three categories namely: firstly, where parties provide information on all space objects, including non-functional objects and objects that are generated during and after launch, including objects generated though impacts; secondly, where parties provide information on functional objects and 
address the status of objects that have not been registered. ${ }^{28}$ Although jurisdiction serves as an incentive for registration, the exercise of jurisdiction and control is necessary for the fulfillment of international responsibilities. ${ }^{29}$

The Outer Space Treaty makes explicit reference to the term 'jurisdiction and control', establishing a legal relationship between a state of registry and its space object. ${ }^{30}$ Lafferranderie argues that 'jurisdiction and control' are interrelated and cannot exist in isolation, explaining that '[j]urisdiction should induce control, and control should be based on jurisdiction'. ${ }^{31}$ More importantly, the nature and responsibilities shadowing 'jurisdiction and control' ensure the fulfillment of a state's international obligations. ${ }^{32}$ Coupled with the right to jurisdiction, the Outer Space Treaty insists on the obligation to exercise such jurisdiction. ${ }^{33}$ It is not advised that that the provision 'shall retain' be interpreted restrictively as it is unlikely that the drafters of the Outer Space Treaty intended to create a right without a corresponding obligation. ${ }^{34}$

Such obligations become increasingly important in the light of Article IX of the Outer Space Treaty, which provides that where necessary, states partly shall adopt appropriate measures to avoid the

non-functional objects that are produced during or just after launch; and thirdly, where parties provide information on functional objects only. Although the first method of registration is the most ideal, its practical limitations result in states adopting the second category of registration, nevertheless, the Registration Convention's failure to address a preferred system of registration leaves such a decision to be determined by state practice. Although I agree that such deficiencies require revision, I am more concerned about the failure to address the status of objects constructed from material in outer space. Further, the fragility of the moon's environment renders immediate action necessary to preserve the common interest of both contemporary and future generations, in the exploration and use of outer space. Jurisdiction plays a pivotal role in this regard by requiring such a state to give effect to the obligations created by the Outer Space Treaty in its various provisions.

Schmidt-Tedd \& Mick (n 17 above) 157; LE Viikar 'The legal regime for moon resource utilisation and comparable solutions adopted for deep seabed activities' (2003) 31(1) Advances in Space Research 2427-2428.

$30 \mathrm{G}$ Lafferranderie "Jurisdiction and control of space objects and the case of international inter-governmental organisations (ESA)' (2005) 54 Zeitschrift für Luft- und Weltraumrecht 230; Outer Space Treaty (n 6 above) art VI \& IX; Schmidt-Tedd \& Mick (n 17 above) 150. The element of control has been defined to include '[the] adopt[ion] of technical rules to achieve the space object mission'.

G Lafferranderie (n 30 above) 231

Viikari (n 29 above) 2427-2428.

Schmidt-Tedd \& Mick (n 17 above) 158.

4 Schmidt-Tedd \& Mick (n 17 above) 158; G Gál Space Law (1969) 215; H Bittlinger Hoheitsgewalt und kontrolle in weltraum (1988) 33; Outer Space Treaty (n 6 above) art I \& IX. In my opinion this position is further supported by the character of the Outer Space Treaty, which - at its core - protects the interests of those states that have yet to reach space-faring capability. See UN GAOR 21st Sess. 57th mtg. at 12 UN Doc. A/AC.105/C.2/SR.57 (20 October1966). Moreover principles such as those of 'due-regard', 'common interest' and 'co-operation' create a code of a conduct and essentially an obligation to ensure that these principles are upheld. 
harmful contamination of the moon's environment. ${ }^{35}$ As space law is a relatively new lex specialis of international law, the Outer Space Treaty provides for the application of general international law to assist in the interpretation of space law principles. ${ }^{36}$ The requirement of 'lunar-protection' finds a second voice in customary international law, which provides that 'states have a duty to carry out activities [...] in common spaces with regard for the right of other states'. ${ }^{37}$ Included in this duty, is the obligation to ensure that the use of a state's territory is limited to activity that will not damage the environment. ${ }^{38}$ In addition, jurisdiction plays a leading role in domains like intellectual property rights, data policies, as well as access to technology. ${ }^{39}$

The exercise of jurisdiction and control is of paramount importance, especially in the plight to achieve environmental protection and sustainable development. Moreover, it is invaluable in matters requiring either criminal or civil jurisdiction. A system of registration that does not regulate the vesting of jurisdiction in every instance is worrying, as it risks crippling the objective of the obligations demanded by the Outer Space Treaty.

\section{Structures that do not constitute 'objects launched into outer space'}

The effect of the non-appropriation principle is the replacement of state sovereignty with a concept of jurisdiction over a space object instead of state territory. ${ }^{40}$ Both the Outer Space Treaty and the Registration Convention rely on the expression 'space object launched into outer space' ${ }^{41}$ This reliance is problematic as the term 'space object' remains inadequately defined. ${ }^{42}$ The Registration and Liability Conventions both provide that "the term "space object" includes component parts of a space object as well as its launch vehicle and parts thereof'. ${ }^{43}$ The fundamental problem with this definition is that it refers back to the space object when speaking of 'component' parts and 'its' launch vehicle. ${ }^{44}$ Practice does however suggest a common understanding of the term 'space object'. ${ }^{45}$ The

\footnotetext{
Outer Space Treaty (n 6 above) art IX.

Outer Space Treaty (n 6 above) art III.

P Birnie \& A Boyle International law and the environment (2002) 104.

A Cassese International law (2001) 382.

Lafferranderie (n 30 above) 231.

Lafferranderie (n 30 above) 229.

Outer Space Treaty (n 6 above) art VIII; Registration Convention (n 13 above) art 2.

Schmidt-Tedd \& Mick (n 17 above) 150.

Liability Convention (n 13 above) art I; Registration Convention (n 13 above) art 1.

S Gorove "Towards a clarification of the term "space object" - an international legal policy imperative' (1993) 21 Journal of Space Law 12.

Schmidt-Tedd \& Mick (n 17 above) 150.
}

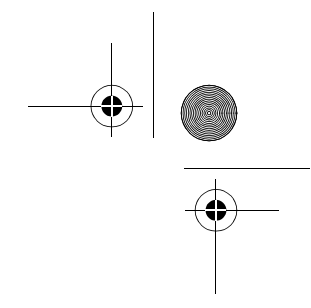


term is understood to broadly include every object that is launched, or intended to be launched, into outer space. ${ }^{46}$ The above expression creates two qualifying criteria in order for registration to be possible; namely that the object in question is man-made and that the object is launched into outer space. ${ }^{47}$ It is unclear if an object constructed in outer space can in fact be registered, as there is no 'launch'.

The International Space Station (ISS) serves as an example of such an object, as components of the station are launched into outer space separately and later constructed into the 'final' object. ${ }^{48}$ Gorove attempts a clarification of the term 'space object', making reference to the ISS: ${ }^{49}$

The issue that policy makers faced was whether such a station should be conceived as a single space object with the various elements being regarded as the object's component parts or whether it should be taken to constitute a cluster of different space objects requiring separate registration. The latter had notable relevance in connection with the exercise of jurisdiction and control.

This problem was addressed in the US International Space Station Agreement that requires each partner state to register each of the 'flight elements' that it provides. ${ }^{50}$ In this regard, by way of a multilateral agreement, the US International Space Station Agreement provides a desired system of registration. However, the Registration Convention does not provide such clarification. The question as to whether each piece of a space object requires separate registration offers various complicated considerations. ${ }^{51} \mathrm{~A}$ restrictive system of registration threatens the ability to identify a space object while an over-detailed registration risks clouding the clarity of the register as a whole. ${ }^{52}$

Although the Registration Convention has not outlined an exact system of registration, it is desirable to consider a broad interpretation of the term 'space object'. ${ }^{53}$ In addition, SchmidtTedd and Mick agree that although state practice varies in the systems of registration that are applied, it is essential that a space object is of Member States of the European Space Agency, the Government of Japan, and the Government of Canada on the Co-operation in the Detailed Design, Development, Operation and Utilization of the Permanently Manned Civil Space Station (US International Space Station Agreement) art 5.

51 Schmidt-Tedd \& Mick (n 17 above) 154

52 As above.

L Perek 'Management issues concerning space debris' (2005) ESA, Proceedings of the 4th European Conference on Space Debris 587, 589.

M Hintz 'Weltraumgegenstände' in K-H Böchstiegel (ed) Handbuch des weltraumrechts (1991) 157; W von Kries et alGrundzüge des ramfahrechts (2002)

Schmidt-Tedd \& Mick (n 17 above) 154.

NASA 'International space station' 9 September 2006 http://www.nasa.gov/

mission_pages/station/main/iss_construction.html (accessed 10 August 2013).

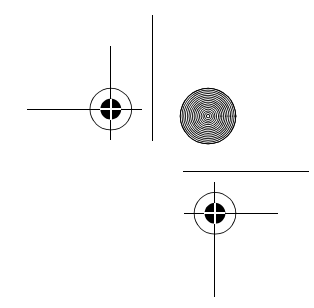

(1)


registered upon entering outer space in order to clarify 'the status of its jurisdiction and control'. 54 As the definition of a 'space object' expressly includes 'component parts', constructing the 'final' object in outer space should not have any bearing on jurisdiction and control - provided that each element has been registered.

\section{Objects constructed from lunar resources}

There is no question that space law foresaw that outer space and the moon would be used for commercial purposes. ${ }^{55}$ Hobe argues that the term 'use' provided by the Outer Space Treaty should be interpreted to include both non-commercial and commercial exploitation of outer space. ${ }^{56}$ The freedom of commercial use, however, generally carries legal concern mostly owed to appropriation and the 'sharing of common space resources' ${ }^{57}$ It is unclear whether the drafters of the Outer Space Treaty envisioned the commercial use of outer space to include the construction of objects from lunar resources. In considering such a construction, two questions should be considered. The first being, whether such a construction is lawful and the second being, to what extent a state may exercise jurisdiction over such an object without its actions constituting national appropriation.

\subsection{The use of lunar resources in the construction of a space object}

A defence for the commercial exploitation of outer space often battles to find a voice in the requirements of Article I, specifically as far as the provision protects the 'interests of all states'. ${ }^{58}$ There are at least four positions representing the varying opinions on the legality of the commercial use of outer space: ${ }^{59}$

(a) all commercial activity in space is unlawful as it is pursued for the benefit of one - or few - state, and therefore is in direct contravention of the 'common interest' principle of Article I of the Outer Space Treaty;

(b) commercial activity in space is lawful to the extent that it embodies an element of 'community service' to all states; 60

54 n 17 above, 155.

55 Outer Space Treaty (n 6 above) art 1.

56 S Hobe 'Article I' in S Hobe, B Schmidt-Tedd \& KW Schrogl (eds) Cologne commentary on space law (2009) 35.

57 A Kerrest 'Commercial use of space, including launching' in China Institute of Space Law Space law conference: paper assemble (2004) 199.

$58 \mathrm{R} J$ Lee 'Creating a practical legal framework for the commercial exploitation of mineral resources in outer space' unpublished PhD thesis, Murdoch University, 2009321.

59 Lee (n 58 above) 324-325.

Such a service may be provided at either no cost or a nominal cost. See Amended Convention on the International Mobile Satellite Organisation, art 3. 
(c) commercial activity in space is lawful provided that the goods or services that are produced may be purchased by a third party state or consumer on the basis of equality and without discrimination of any kind; ${ }^{61}$ or

(d) commercial activities in space are lawful to the extent that it does not prevent any other commercial or non-commercial entity from undertaking the same activity.

The disagreement between the four positions can be settled by relevant state practice and opinio juris. ${ }^{62}$ Principle XII of the Principles Relating to Remote Sensing of the Earth from Outer Space provides that the sensed state will have access to the data obtained 'on a non-discriminatory basis on a reasonable cost term' ${ }^{63}$ Lee concedes however that there is no such equivalent requirement for any other commercial space exploitation, provided that the 'fruit' of such activity is made available to third party states or entities on the basis of non-discrimination. ${ }^{64}$ I therefore submit that the freedom to use outer space for economic ends is permitted by Article 1. ${ }^{65}$ Through Article VI, the Outer Space Treaty permits both government and private entities to enjoy the goal of economic profit. ${ }^{66}$

Hobe goes as far as to argue that an activity will only be excluded if it is prohibited elsewhere in the treaty. ${ }^{67}$ Hobe's position should not be mistaken as overly liberal as the limitations that he recognises within Article I are nevertheless restrictive. ${ }^{68}$ The Outer Space Treaty establishes a code of conduct encompassing a precautionary approach. ${ }^{69}$ As such, space law has excluded the ordinary use of the principle 'what is not prohibited is permitted'. 70 As quoted by Vereshchetin, Judge Lachs argues: ${ }^{71}$

[The above principle] is not valid today. The freedom of action is determined by the possibility of infringing upon the rights of others. Hence the limitation of rights and the need for co-operation and

Remote sensing principles, principle XII.

Lee (n 58 above) 325.

Principles relating to remote sensing of the Earth from outer space, principle XII. Lee (n 58 above) 326.

As above; Hobe (n 56 above) 35.

n 6 above, art VI; M Gerhard 'Article VI' in S Hobe, B Schmidt-Tedd \& KW Schrogl (eds) Cologne commentary on space law (2009) 109; S Hobe (n 56 above) 35.

Hobe (n 56 above) 35.

n 56 above, 36-39; Jakhu (n 11 above) 39. Hobe concedes that the extent to which the 'benefits and interest of all states' provision should be applied is doubtful and that its interpretation should rely on state practice. Nevertheless, Hobe does make reference to the importance of the 'due regard' principle as a limitation on the freedoms provided by Article I of the Outer Space Treaty and seems to be in support of Jahku's argument that 'space activities are not granted in an unlimited way, but only under the condition that such activities are undertaken for the common benefit of all states'.

69 P B Larsen 'Application of the precautionary principle to the moon' (2006) 71 Journal of Air Law and Communications 299.

70 Jakhu (n 11 above) 42

71 V S Vereshchetin 'Against arbitrary interpretation of some important provisions of international space law' (1982) 25 Colloquium on the Law of Outer Space 153. 
consultation in all cases where a state may by its activity affect the rights of others. This is of particular importance in regard to outer space.

This position was supported by Vlasic, who criticised that: ${ }^{72}$

Major space powers have demonstrably been acting on the premise that whatever is not prohibited verbis expressis by the treaty is permissible, and therefore lawful. While the document as a whole does not permit such an interpretation, the muddle text of Article IV can be used, and has been used, to undermine the legally and politically sounder interpretation.

In stressing the common interest shared by all states in the 'exploration and use of outer space', the Outer Space Treaty ensures that the 'Lotus case [-which provided the principle of 'what is not prohibited is permitted'-] does not constitute a precedent in favour of unrestricted national uses and activities in outer space'. ${ }^{73}$ The Chilean delegate to the COPUOS legal subcommittee elaborate on what constitutes an abuse of freedom by stating that: ${ }^{74}$

[E]xploration and use of outer space [is] lawful only if [it seeks] to satisfy the needs of mankind as a whole, and in particular those of the poorest nations. Otherwise [such activity] would constitute an abuse of rights.

The above comments have assisted in creating a culture of consideration that is underpinned by the principle of 'due regard' and the need to protect the interests of both contemporary and future generations. For these reasons, I share Larsen's opinion that the precautionary principle is applicable in regulating state activity in the exploration and use of outer space. ${ }^{75}$

It is likely that the construction of an object from lunar resources threatens to undermine the precautionary approach underscored by the five space law treaties. ${ }^{76}$ The Moon Agreement demands that states be cautious of disrupting the moon's environmental balance, going as far as to permit the designation of 'international scientific preserves for which special protective arrangements are to be agreed upon'. ${ }^{77}$ The approach adopted by the International Court of Justice

72 I Vlasic 'Disarmament decade, outer space and international law' (1981) 26(2) McGill Law Journal 171.

C Christol International law of outer space (1962) 267.

U.N. GAOR, 21st Sess. 362nd mtg. at 2, UN Doc A/AC.105/C.2/SR.362 (1982).

Larsen (n 59 above) 301.

At this point I would like to differentiate between the construction of a space object 'using' lunar resources and the construction of such an object 'from' lunar resources. The former would include the mining of lunar resources which would then be processed into a final product; in contrast the latter involves the removal of lunar resources to be used in their raw form as an element in the construction of a space object. I will not elaborate on the lawfulness of lunar mining, but instead focus this paper on the lawfulness of constructing a space object from lunar resources.

77 As above; Moon Agreement (n 13 above) art 7. 
(ICJ) in the Gabcikovo-Nagymaros case is similarly echoed by the relevant practice of outer space activities. ${ }^{78}$ In the GabcikovoNagymaros case the court noted that: ${ }^{79}$

Throughout the ages, mankind has, for economic and other reasons, constantly interfered with nature. In the past, this was often done without consideration of the effects upon the environment. Owing to new scientific insights and to a growing awareness of the risks for mankind - for present and future generations - of pursuit of such interventions at an unconsidered and unabated pace, new norms and standards have been developed, set forth in a great number of instruments during the last two decades. Such new norms have to be taken into considerations [...] when [s]tates contemplate new activities [...]. This need to reconcile economic development with protection of the environment aptly expressed in the concept of sustainable development.

This movement towards sustainable development has been well received by states and evident particularly in their growing tendency to tackle the problem of environmental preservation of outer space and protecting the space environment to the greatest extent possible. ${ }^{80}$ Various instruments have been used to achieve this purpose, for example the International Charter on Space and Major Disasters, which assists in the preparation of risk-related events, as well as the adoption of the Committee of Space Related Research (COSPAR) Planetary Protection Policy, which aims at providing acceptable guidelines to prevent planetary contamination. ${ }^{81}$ Most recently, the US introduced the Apollo Lunar Landing Legacy Bill recognising the need to protect the scientific data and cultural significance of the Apollo artefacts as well as the benefit of ensuring that they remain unharmed by future lunar landings. ${ }^{82}$

The actions of states are only lawful to the extent that they do not conflict with the rights and interests of other states. The fragility of the moon's environment would render the use of lunar resources in the construction of space objects unlawful. ${ }^{83}$ It appears that commercial activity is permitted if it does not become a mechanism

S Marchisio 'Article IX' Treaty' in S Hobe, B Schmidt-Tedd \& KW Schrogl (eds) Cologne commentary on space law (2009) 178

Hungary v Slovakia ICJ (25 September 1997) (1997) ICJ Reports 7.

Marchisio (n 78 above) 178. (accessed 11 August 2013).

Apollo Lunar Landing Legacy Act http://www.govtrack.us/congress/bills/113/ hr2617/text (accessed 11 August 2013). It is arguable that the provisions of the Bill amount to national appropriation as they facilitate the creation over a demarcated heritage park around part of the moon. I will not discuss the legality of such a Bill as I am more concerned about the movement that it supports. Consequently, although the means of achieving the intended protection may be rejected by the international community, the Bill is an indication of international concern regarding the protection of the moon's environment.

PB Larsen ( $\mathrm{n} 59$ above) 298. For a discussion on the fragility of the moon's environment. 
for discrimination. More importantly however, such activity must not threaten the balance of the moon's environment as such action would directly infringe upon the interests of non-space-faring nations, as well as future generations. At its very core, the Outer Space Treaty seeks to protect the interests of mankind by setting a standard that is mandated by the principle of due regard. ${ }^{84}$ As the construction of a space object from lunar resources would deny the subsequent use of such resources, the construction of an object from lunar resources would be unlawful.

\subsection{The exercise of jurisdiction over objects constructed from lunar resources amounts to national appropriation}

Although it is likely that the construction of such an object is unlawful, it is the status of such an object that is of interest. General international law provides a number of well accepted modes of acquisition of territory namely: by way of conquest, occupation, prescription, cession and/or accretion. ${ }^{85}$ The extra-territorial character of space renders the use of such modes inappropriate. ${ }^{86}$ Space law is quite clear in emphasising a prohibition on national appropriation. ${ }^{87}$ The non-appropriation principle of Article II received almost immediate acceptance and remained a largely uncontested provision. ${ }^{88}$ In his dissenting opinion in the North Sea Continental Shelf case, Judge Lachs makes reference to this principle as adopted by the Outer Space Treaty: ${ }^{89}$

The first instrument that men sent into outer space traversed the airspace of states and circled above them in outer space, yet the launching states sought no permission, nor did the other states protest.

This is how the freedom of movement into outer space, and in it, came to be established and recognised as law within a remarkably short period of time.

The view that outer space should be free from property rights has been maintained from the start of the space age. ${ }^{90}$ Goedhuis asserted that 'it was realised that by denying the legality of such [sovereignty] claims the interest of the world community as a whole would best be

$\mathrm{J}$ Thomas 'Privatisation of space venture proposing a proven regulatory theory for future extra-territorial appropriation (2005) 1 International Law and Management Review 191; S Freeland \& R Jakhu 'Article II' in S Hobe, B Schmidt-Tedd \& KW Schrogl (eds) Cologne commentary on space law (2009) 46. Although there have been proposals that 'traditional property jurisprudence' be applied to outer space acquisitions, this would require the re-interpretation of the principles of non-appropriation.

87 Outer Space Treaty (n 6 above) art II.

88 Freeland \& Jakhu (n 86 above) 45, 47.

89 Republic of Germany $v$ Denmark and Federal Republic of Germany $v$ The 90 Netherlands ICJ (20 February 1969) (1969) ICJ Reports 3. Freeland \& Jakhu (n 86 above) 51. 
served'. President Lyndon B Johnson emphasised the importance of the non-appropriation principle in saying that: ${ }^{91}$

In November 1958, President Dwight D Eisenhower asked me to appear before the United Nations to present the US resolution [on outer space] [...].On that occasion, speaking for the United States, I said: 'Today, outer space is free. It is unscarred by conflict. No nation holds concession there. It must remain this way. We of the United States do not acknowledge that there are landlords of outer space who can presume to bargain with the nationals of the Earth on the price of access to this domain[...]'. I believe those words remain valid today.

Freeland and Jakhu go as far as to call the prohibition of national appropriation a jus cogens norm and one that has been observed by states from the start of the space age. ${ }^{92}$ In the context of outer space appropriation implies the 'exercise of exclusive control or use and denial of use of others' ${ }^{93}$ The non-appropriation provision is broad by prohibiting appropriation by 'claims of sovereignty' or 'means of use or occupation' ${ }^{94}$ Further, the insertion of 'other means' permanently excludes appropriation in any form. ${ }^{95}$

The principle of non-appropriation has an inclusive character and to a large extent is inflexible. The increase in mankind's interest in outer space and its ability to participate in a spectrum of activities has introduced various legal challenges. ${ }^{96}$ In citing Goedhuis, Sittenfeld notes that ' $\mathrm{t}$ ] he traditional territorially orientated concept of sovereignty is engaged in a particularly slow and problematic reconciliation with current developments in outer space'. ${ }^{97}$ The Moon Agreement provides a more commercially desirable interpretation of the principle, which does not include the exploitation of natural resources as national appropriation. ${ }^{98}$ Admittedly, the Moon Agreement has not received the same support as the preceding four space-law treaties. ${ }^{99}$ Be that as it may, the Moon Agreement is intended to be an expansion of the Outer Space Treaty and therefore complements the core principles of space law. ${ }^{100}$ Although the agreement does repeat the non-appropriation principle, it does so in the context of the 21st century's commercial necessities by providing a backdrop to promote the exploitation of

'Treaty on outer space: hearing before the committee on foreign relations' 90th Congress (1967) 105-196.

Freeland \& Jakhu (n 86 above) 55.

Jakhu (n 11 above) 44.

Outer Space Treat (n 6 above) art II.

As above.

LR Sittenfeld 'The evolution of a new and viable concept of sovereignty for outer space' (1980) 4 Fordham International Law Journal 199.

Sittenfeld (n 96 above) 199-200.

Moon Agreement (n 13 above) art 11(2) \& (3).

Having been ratified by only 13 states, of which only Australia is likely to be considered to have space-faring capability.

EM Galloway 'Agreements governing the activities of states on the moon and other celestial bodies' (1980) 5 Annual Air \& Space Law 498-499. 
lunar resources and the establishment of an international regime. ${ }^{101}$ Freeman and Jakhu conclude this point by stating: ${ }^{102}$

[T] his prohibition [of national appropriation] would not prevent public or private entities from receiving [...] what might be termed as 'extraterrestrial exploitative rights' in relation to the natural resources of outer space, although they must, of course, comply with the principles set out in the space treaties [...]. Such rights are consistent with the res communis nature of outer space, since the natural resources to which they relate remain part of the 'common heritage of mankind' [...].

The Moon Agreement makes reference to the prohibition of ownership rights over 'natural resources in place'. ${ }^{103}$ It is therefore questionable if the use of lunar resources in the construction of a space object would constitute appropriation, or if the Moon Agreement intends to differentiate in this regard. In Article 6(2) the agreement provides several rights to states, in each case however, the right is confined to scientific purpose. ${ }^{104}$ Lee argues that under certain circumstances a commercial activity, no matter how capitalistic in nature, may yield scientific benefit and in doing so blurs the lines between what is permitted and what is prohibited. ${ }^{105}$ Even in such arguments however, Lee restricts his discussion to either the collection of data or commercial mineral prospecting activities, leaving construction of a space object 'from' lunar resources largely unaddressed. ${ }^{106}$

\section{Conclusion}

AG Haley states that law must precede man into space. ${ }^{107}$ Mankind's need to regulate outer space activities was quickly recognised from the start of the race to the moon. The development of the Outer Space Treaty was achieved within the multilateral framework of the UN. ${ }^{108}$ In a speech made by US President JF Kennedy, he explained

101 Moon Agreement (n 13 above) art 11(7). The international regime envisioned by the Moon Agreement provides:

'The main purpose of the international regime to be established shall include:

(a) The orderly and safe development of natural resources of the moon;

(b) the rational management of those resources;

(c) the expansion of opportunities in the sue of those resources;

(d) an equitable sharing by all states parties in the benefit derived from those resources, whereby the interests and needs of developing countries, as well as the efforts of those countries which have contributed either directly or indirectly to the exploration of the moon, shall be given special consideration."

103 Freeman \& Jakhu (n 86 above) 60

103 Moon Agreement (n 13 above) art 11(3).

104 Moon Agreement (n 13 above) art 6(2).

105 Lee (n 58 above) 368

106 As above.

107 Haley (n 1 above) 5

108 Hobe (n 2 above) 14. 
why man was inherently drawn to the mystique of the unknown universe: 109

We choose to go to the moon. We choose to go to the moon in this decade and do the other things, not because they are easy, but because they are hard, because that goal will serve to organise and measure the best of our energies and skills, because that challenge is one that we are willing to accept, one we are unwilling to postpone, and one which we intend to win, and the others, too.

Since the adoption of the Outer Space Treaty in 1969, scientific and commercial development has progressed tremendously and therefore demands the continuous development of space law. ${ }^{110}$ Danilenko comments on mankind's stagnated response to the once rapid development of outer space policy: ${ }^{111}$

For a certain period, which may be described as the "golden age" of space law-making, rapidly developing space activities were accompanied by the adoption of a number of general multilateral treaties which deal exclusively with outer space and space activities. Despite the adoption of these treaties and related conventions, however, key issues remain unresolved. Continuous law-making is essential to ensure a viable and coherent system of space law.

In this paper I have attempted to criticise the lack of development of the Registration Convention, which in a time of commercial and scientific lust, requires urgent revision. I posed two questions, namely whether the Registration Convention addressed the status of objects constructed in outer space, and whether the exercise of jurisdiction over an object constructed from lunar resources would be possible.

With regards to the first question, I am satisfied in concluding that provided that the elements of a space object are launched into outer space, the object's extraterrestrial construction should have no bearing on its status. ${ }^{112}$ Using the ISS as a reference, a state would be able to exercise quasi-territorial jurisdiction over the individual elements of the object and registration of the object in its entirety would not be required. ${ }^{113}$ Consequently, state practice in this regard accommodates the Registration Convention's failure to expressly address such an occurrence.

What is more worrying is the failure to address the status of an object that has been constructed from lunar resources. I am in the opinion that such a construction would violate a number of core

109 JF Kennedy 'Moon Speech' 15 September 1962 http://er.jsc.nasa.gov/seh/ ricetalk.htm (accessed 12 August 2013).

110 Hobe (n 2 above) 14.

11 GM Danilenko 'Outer space and the multilateral treaty making process' http:// www.law. berkeley.edu/journals/btlj/articles/vol4/Danilenko.pdf (accessed 12 August 2013)

112 NASA (n 48 above).

113 US International Space Station Agreement (n 50 above) art 5. 
principles that already govern activities in outer space. A precautionary approach towards outer space activities is implied by the importance that the space law endows upon the common interest principle. ${ }^{114}$ The fragility of the moon's environment would render the construction of such an object an abuse of freedom. My second enquiry leads to me to the question of how jurisdiction would be vested in terms of such an object.

Although I am wary of conceding that such a construction would be lawful it is desirable to determine the hypothetical legal status of such an object. The Moon Agreement does not seem to consider the exploitation of the moon's resources to constitute appropriation; however its provision for such activity seems to be contained within a scientific motive. ${ }^{115}$ As such, I am not convinced that the exercise of jurisdiction over parts of the moon - albeit no longer in place - would not constitute an act of appropriation by means of sovereignty.

Should the international community elect to declare the construction of an object from lunar resources to be lawful; and further elect to deem the exercise of jurisdiction over such an object to be lawful, the Registration Convention would nevertheless require revision. For the vesting of jurisdiction to be possible registration is considered a prerequisite. ${ }^{116}$ Moreover, for an object to be capable of registration it must be both man-made and have been launched into outer space. ${ }^{117}$ In terms of an object constructed from lunar resources both of the above qualifying criteria would not be met and registration would not be possible. Subsequently, no state would be vested with jurisdiction and such an object would suffer without a legal regime. I recommend a revision of the Registration Convention to accommodate the commercial and scientific demands of the 21st century. Either through the introduction of an expressed provision regulating an occurrence that was clearly unforeseen by drafters of the treaty; or by limiting the right to jurisdiction, once again, subjecting it to the already established common interest principle. My latter suggestion allows for the development of space law within the current framework of treaty law. As a right vested in terms of the Outer Space Treaty, jurisdiction is not absolute and perhaps a revision of the Registration Convention could translate the principle of jurisdiction into a principle more familiar to outer space.

\footnotetext{
114 Larsen (n 69 above) 297; Outer Space Treaty (n 6 above) art I.

115 Lee (n 58 above) 368; Freeland \& Jakhu (n 86 above) 59.

116 Hobe (n 28 above) 447.

117 Schmidt-Tedd \& Mick (n 17 above) 154.
} 